\title{
MODULARES: AN ARTISTIC EXPERIENCE BETWEEN CONSTRUCTION AND VISUAL NOISE
}

\author{
Susana Jodra Llorente \\ Universidad del País Vasco /Euskal Herriko Unibertsitatea. Dpto. Dibujo
}

\section{Patricia Schneider}

Hochschule der Künste Bern (HKB)

\begin{abstract}
In our screen printing process we work with specific images from our photographic archives and plans from different sources, that we use as modules for our series of unique prints. By modulating the images in size, intensity and location, we have been building collages with up to twenty layers. The Modulares Art Project, which we developed in the last three years, allowed us to investigate the evolution of our creative process by revising pictures of previous years. We created compositions by adding and subtracting geometric forms and elements of concrete pictures, printing them layer by layer. Through this process, visual echoes of the subjacent layers that interfere with the reading of the message have been silenced or in some cases emphasized. The noise and visual disturbances of the underlying information are also object of our interest as they give the interaction between the different images a temporal dimension.
\end{abstract}

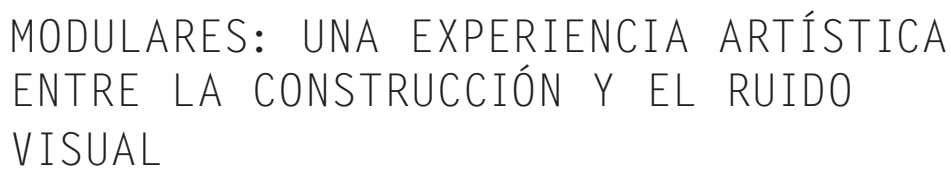

\section{Resumen}

En nuestro proceso de impresión serigráfica trabajamos con imágenes específicas de archivos fotográficos propios y motivos de diferentes fuentes, que utilizamos como módulos en series de impresiones únicas. Modulando las imágenes en tamaño, la intensidad y la ubicación, construimos collages de hasta veinte capas. El Proyecto Artístico Modulares, que hemos desarrollado en los últimos tres años, nos ha permitido investigar la evolución de nuestro proceso creativo mediante la revisión de las estampas de años anteriores. Hemos creado composiciones mediante la adición y la sustracción de formas geométricas y elementos de imágenes concretas, imprimiéndolas capa a capa. A través de este proceso, los ecos visuales de las capas subyacentes que interfieren en la lectura del mensaje han sido silenciados o en algunos casos enfatizados. El ruido y perturbaciones visuales de la información subyacente también son objeto de nuestro interés, ya que la interacción entre las diferentes imágenes aporta una dimensión temporal.

\section{Palabras clave: MODULAR; MÓDULO; COMPOSICIÓN; RUIDO; IMPRESIÓN SERI-} GRÁFICA

\footnotetext{
Jodra Llorente, Susana \& Patricia Schneider. 2015. "Modulares: an artistic experience between construction and visual noise / una experiencia artística entre la construcción y el ruido visual". AusArt 3 (2): 269-282. D0I: 10.1387/ausart.15974
}

\section{AUSART}




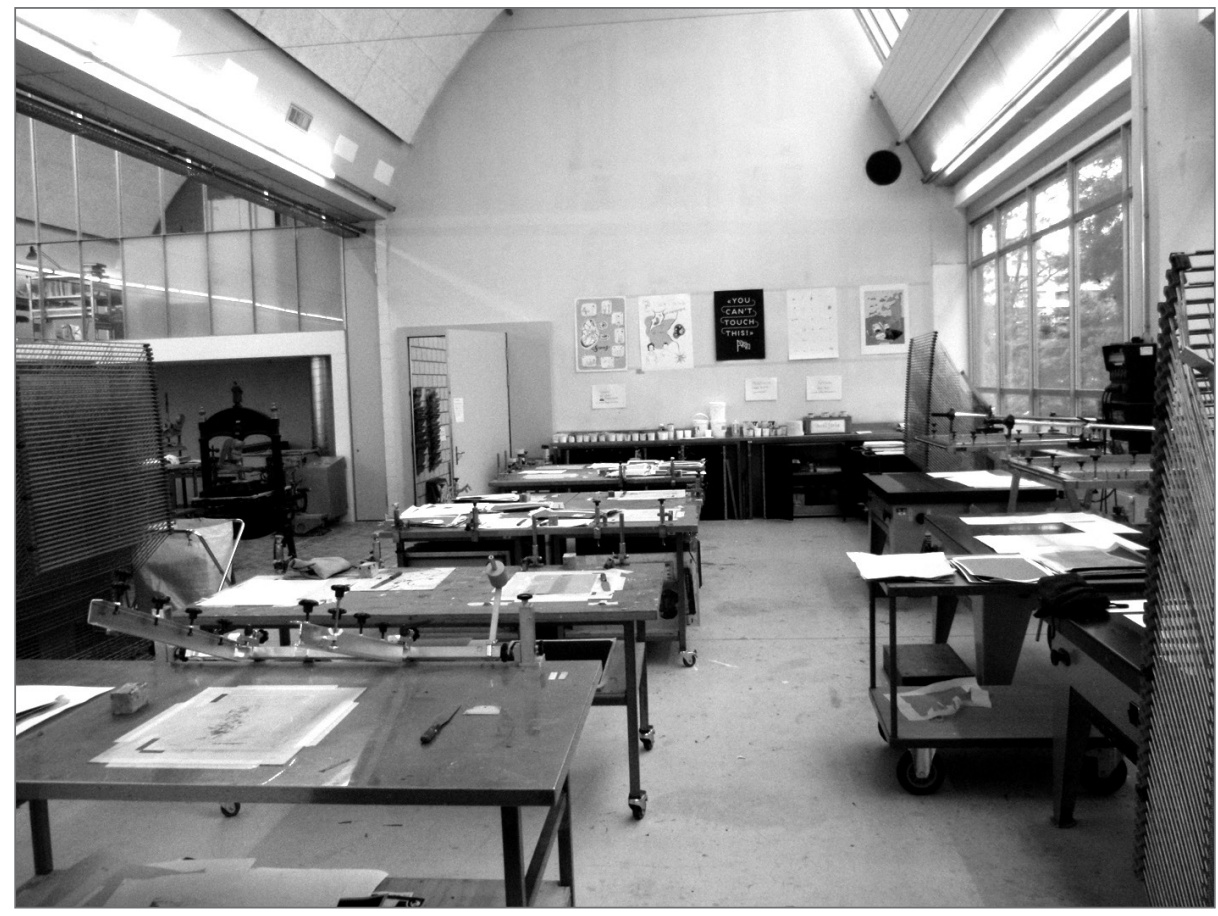

Image 1. Workshop HKB Bern Bümpliz Nord

\section{PRINTING PROCESS}

Screen printing is our technical working tool and our medium of artistic expression, which gives us the ability to photographically reproduce all kinds of images. The water-based inks allow us to print uniformly opaque or transparent color planes to cover or complement the previous layers, as it has been done by artists of the Pop-Art. These technical qualities of the inks combined with the variety of different surfaces make screen printing a versatile medium for our artistic interests. The manual skills and the ability of joined-up thinking are important preconditions to use the medium in this experimental way. 
Although screen printing is a very technical medium with many steps of a procedure, for us it is as natural to work with the required tools and materials as to use a brush or a pencil. The slow working process gives us the time to develop and to consolidate our artistic intentions. As we are both very familiar with the technique, we can concentrate on questions regarding form and content. Our functioning is very precise and well synchronized, in spite of our experimental approach. From the beginning we have been a very good working team, that decides and realizes everything together.

In all graphical techniques there are two processing steps: first the creation of the matrix, and second the printing process, which can also be a creative act. We use the time between these two phases for decisions concerning the print substrate, the color and opacity of the ink and the order of the pattern we are going to print. We spread all our material to reflect and select the unfinished prints for the next production step. As soon as we start the printing process, we have to be quick with our decisions concerning the exact positions of the pattern, as the ink must not dry within the screen. The entire working process contains slow and fast working phases, which requires a high degree of flexibility by taking decisions.
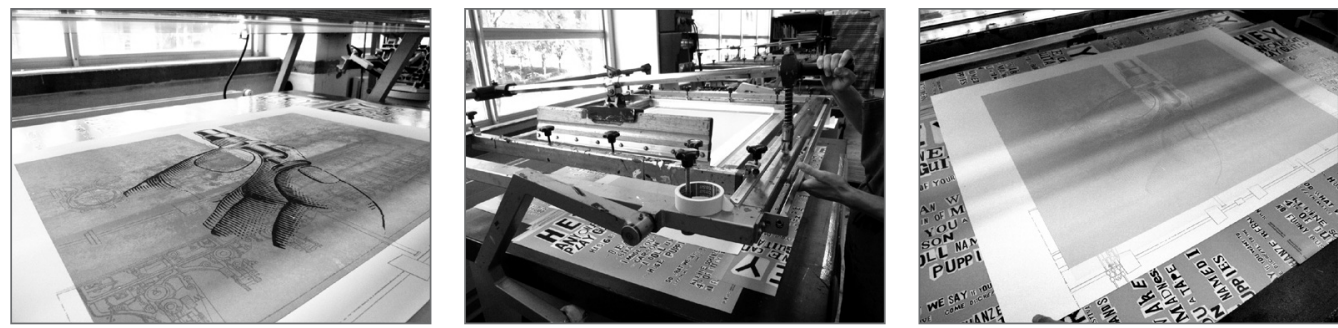

Image 2-4. Screen printing table

The screen can be considered as a temporary support, carrying the selected motifs. On the printing table the images are built layer by layer like a collage. As a result of this process the motifs start to interact with each other, and due to the integrating nature of the silk screen media, the elements merge together und form new shapes. Depending on the combinations of the motifs and the different backgrounds, the compositions are more or less harmonic. In any case they get more complex and form new image spaces. As Beth Grabowski and Bill Fick stated: "If we set aside the idea of the exact copy, the print matrix also contains the idea of an infinite number of variants. The similarity thus becomes an affiliated relationship between prints created from the same orig- 
inating matrix" $(2009,13)$. This "integrating" nature and variability of screen printing is what we want to investigate with our project.

\section{MODULATING}

Printing techniques are used to print editions for functional, cultural and economic reasons. The higher the volume of an edition, the smaller the issue price per printed sheet gets, which in turn allows to spread the work and reach a wider audience. The production of large editions is not what we are interested in. In our screen printing creations, we focus on the evolution and transformations that occur in the prints when we combine our motifs. We investigate the relationships, the different interpretations and the interferences which establish themselves in the prints and between the works. Ultimately we create unique prints that invite to be read in different ways.

Our work is not only a matter of using images as modules, i.e. components that are repeated to construct images. We also try to modulate variations of the same theme by working with different intensities and colors, changing the position of the pattern or using overlapping parts. We repeat our pattern and modify the elements to create different kinds of compositions. It is like the composition of a piece of music that needs to have a structure with a repeating pattern but also lives from its variations and interpretations.

The Modulares Art Project started in the print workshop at the University of the Arts, which is located in a former factory on the outskirts of Berne. We started our work by comparing our picture libraries and searching for similar motifs, which reflect a certain way of seeing. We realized that we were both fascinated by objects with specific characteristics like rusty machines and plans of technical structures. Our photographic collections include unused and undefined objects damaged by the weather, gear wheels and pulleys, architectural fragments, motors, steel structures, etc. Beside the photographs that we have taken ourselves, we have also collected illustrations of old machines and technical schemas of the printing industry and the paper production, taken from encyclopedias, catalogs or specialized books from the beginning of the last century. We are interested in the visual qualities of these images when they interact with each other. 
We recycle what was once printed and extract it from its functional and logical context. With this deconstruction method we create modules to build new combinations of historical illustrations and optionally merge them with our contemporary photographs. We are interested in the formal composition and the resulting relationships between the selected objects. We don't create completely accidental combinations, as all the images deal with production processes. We work with the accident as a principle, but decide after every printing step whether we reject the result or continue with another layer. Finally we are interested in the new content that arises from the new compositions, and based on it we try to launch a discussion about the evolution and the relation between its objects.

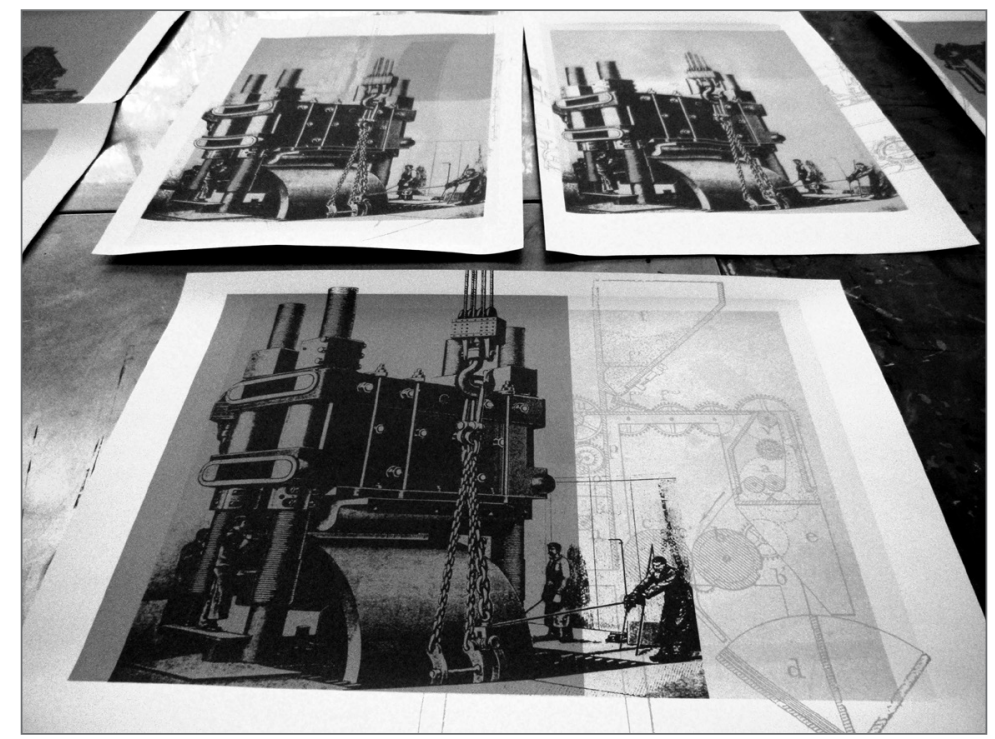

Image 5. Variations with different motifs

\section{WORK IN PROGRESS}

Digital media are part of our working process. All motifs have been digitally processed, regardless of their origin. It is necessary to detach the objects from their background, to determine their size and shape, as well as to remove certain details in order to highlight or isolate the central motif. Photographical images must be transfered into halftone patterns, in order to be used as a screen. We try to preserve the characteristics of the media in which all our 
pictures were originally produced. For the exposure to UV-light we have to produce a film from the required images, which we print with an inkjet plotter or a photocopying machine, being aware that each output medium has its own visual code.

When we meet each other once a year, we focus on the printing process. Before and after our intense working sessions we prepare the films that we have selected together, and search for new material. We don't attempt to provide a particular solution for each print. Our prospect is quite open and consolidates only during the creative exchange.
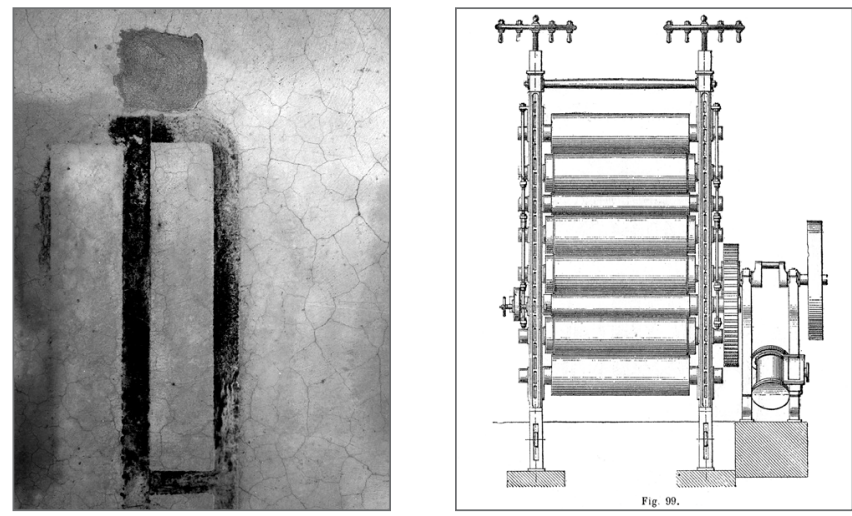

Image 6-7. Illustrations and photographic sources

As already mentioned, the temporality is a very important aspect in our creative process. Some prints have been realized in a single working period and others could only be finished after three years time. As we work with different images every year, we can see the duration of the production from the combination of the motifs. We bring old and new images together and give them a new temporal chronology by using inks with different transparencies - therefore some elements seem to fade away and others look very present.

Using the screen printing technique in an experimental and modular way means that the process cannot be controlled at any point. That is why it is important that we have a mutual understanding of how to deal with mistakes. We produce a big amount of waste to create a couple of effective results. To be able to develop innovative compositions, it is necessary to risk something and to broaden the methods consistently. After working together for three years, we are very efficient in the selection and classification of our intermediate results. 
After every printing session we place our prints on four large tables to get an overview and organize them in groups according to their content. Then we sort them in three groups of prints: the finished, the unfinished and the discarded ones. Finally we assign new motifs to the unfinished ones, which are usually on the majority. They are the basic raw material for our future prints and give the project at the same time some continuity.

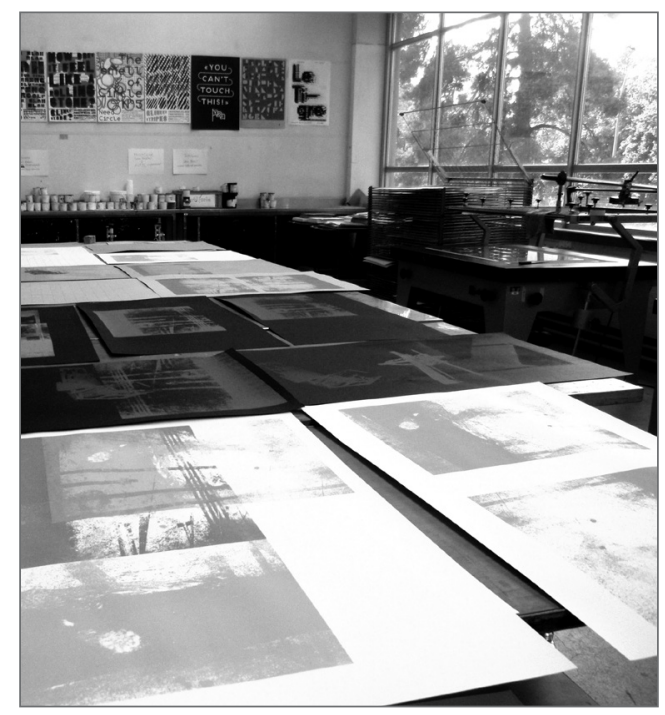

Image 8. Work in progress

\section{TEAMWORK AND VISUAL NOISE}

To select and categorize the unfinished prints in a team is a challenge, as arguments for the personal preferences have to be found. It is easy to sort out prints with technical faults but finding words for unbalanced and irritating impressions is a difficult thing, as the prints with certain irregularities can be the interesting ones. When a composition works fine we agree most of the time very quickly and spend more time to discuss the awkward ones. These discussions are a very interesting part of our team work as they force us to take up a position and to question our practice of making creative decisions. First we have to decide whether the unfinished prints need more or less information. If we want to add some motifs, we put transparent films with these images on top of the prints to test possible combinations. In the opposite case we start a subtractive process 
by overprinting the unfinished prints entirely or partly with flat planes of translucent or opaque color. By varying the transparency of the ink we can determine how much information of the lower layers should shine through. These overprinted works build the fundament of the next compositions, but in contrast to a plain sheet they already contain some information that we call visual noise. The result of this practice is similar to a palimpsest, as we reuse our material as it has been done with manuscript rolls by scraping or washing off the old information. In our case it is not just an interest of economy but mainly a strategy to develop complex images. In his essay Juan Martínez Moro writes about the palimpsest in engraving $(1998,42)$ : "In this way successive languages or work episodes come to melt and fade to the background, leaving a dull echo, a sound void of explicit meanings, although full of evocations. (...) the evidence is the passing of time, this ultimate product of the sequenced working process".

Jesus Pastor $(1998,17)$ refers to a chain of communication when he cites Michael Buhler in his book Electrography and Engraving: "visual noise disturbs transmission and can - due to its signal-concealing properties - theoretically be confused with a second source". The sources of interference can vary, just like elements that can harmonize or not due to their intensity, size, position or number. Too many striking elements or colors capture the attention of the viewer and keep him from reading the main message. In our work we want to find out how much noise the main subject can stand without losing the central focus.

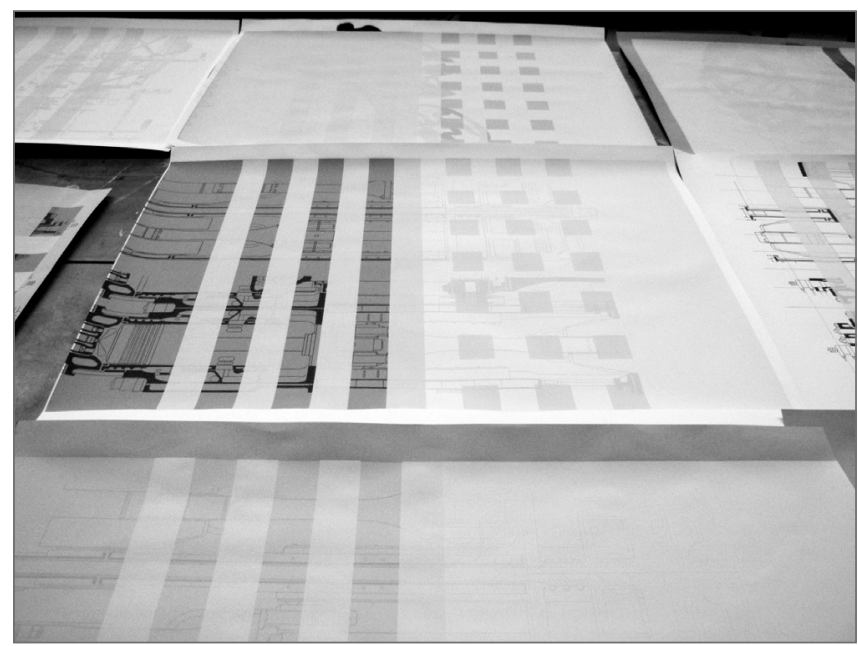

Image 9. Overprinting visual noise 


\section{DEVELOPMENT OF CONTENTS}

In the first working session during the summer 2013 we started to print the desired motifs on white, ocher and black papers, without a concrete concept. We worked on different large and heavy sheets of paper that gave us ample space to play with different compositions. The high quality of the heavy paper was ideal for a continuous printing process, as the surface would not lose its appearance by printing numerous layers. The water based tempera could easily be washed out of the mesh, which gave us the freedom to try many colors.

From the beginning we wanted to work with large-sized motifs, taking advantage of working in a team. We started with a series of photographs of ancient metal tools, that we scaled to the maximum possible printing size. As they are not in use anymore and due to their enlargement, they got detached from the original content and became abstract monumental shapes. To give the printed shapes some structure and an orientation on the large sheets of paper, we added some grids and geometric patterns. As a contrast to the manual working tools, we printed some plans of industrial machines on top, using their structure to build repeat patterns. Like the enlargement process of the working tools, this is a method to modify the information of the original subject. To build our images, we use objects and fragments of production processes - not to illustrate them, but to create image spaces that are rich in indications and references.

In the second session (Summer 2014) we focused on backgrounds picking up traces and textures. We used photographs of the workshop floor, as an evidence of the industrial past of the building, which used to be a factory for textile processing and is now used by the University of the Arts Berne. We reacted to the unfinished prints of the previous year with new illustrations of plans and machines. We covered those which had too much information with white translucent ink, as already mentioned. As new elements we used illustrations of handling and installation instructions that we had taken from a hundred year old catalogue for medical and chemist supply. We were especially interested in the interaction between the machines and the operating hands, independently of the concrete fabrication.

In the third session (Summer 2015) we expanded our repertoire with motifs of the paper and print industry at the beginning of the $20^{\text {th }}$ century. With these illustrations we picked the past of our own working equipment as central theme. The paper is the carrier material and the ink is the preserving medium of the 
information. Together they have been keeping and passing on our knowledge for ages. Huge machines made the production of paper, printed matter and books faster and easier, while the workers had more and more to deal with the handling of the machines and less with the product itself. The machines looked like hulks that had to be fed and controlled by tiny looking men. As a contrast to these narrative images we continued with the construction of plans and schemas that handle the same subject on a more abstract level. With geometric forms, that we took from parts of the mentioned plans, we continued our method of covering unwished information, overprinting the unfinished works of the previous year. For the first time we started to make special patterns that were adapted to a single motif. As in the previous years we produced more unfinished works than definite results.

The method of combining disparate image elements with the technique of image transfer in silkscreen printing has been used by artists like Robert Rauschenberg, Andy Warhol, James Rosenquist and Sigmar Polke. It allowed them to create serial variations and to bring their social, political and cultural concerns in a visual discourse. Favoring the idea over the execution, Warhol even went a step further and delegated the printing process to his colleagues in his factory. While Warhol was repeating the same pattern on the same image, using the screen printing mesh as a stamp, Rauschenberg was more interested in combining different patterns to create compilations between painted and photographical elements. According to Klaus Honeff (1991, 45), "Rauschenberg had incorporated photographs in his paintings as citations within the pictorial space". James Rosenquist used printing to build layers as a supplement to his paintings while Sigmar Polke created series of works experimenting with the raster, the repetition and the material. All of them used the silkscreen technique in a free way and did not care about having a proper transfer of their photographic images.

In our work we don't accept technical mistakes like an irregular transfer or accidental color compositions. Though we use the accident as a method to get multilayered pictures, we try to control the process as far as possible. We always test out both the shade of color and the transparency of the inks as well as the position of an image before we start the printing process. By printing a new motif on a transparent film, that we lay on top of the existing prints, we can check the color combination and simulate possible compositions. 

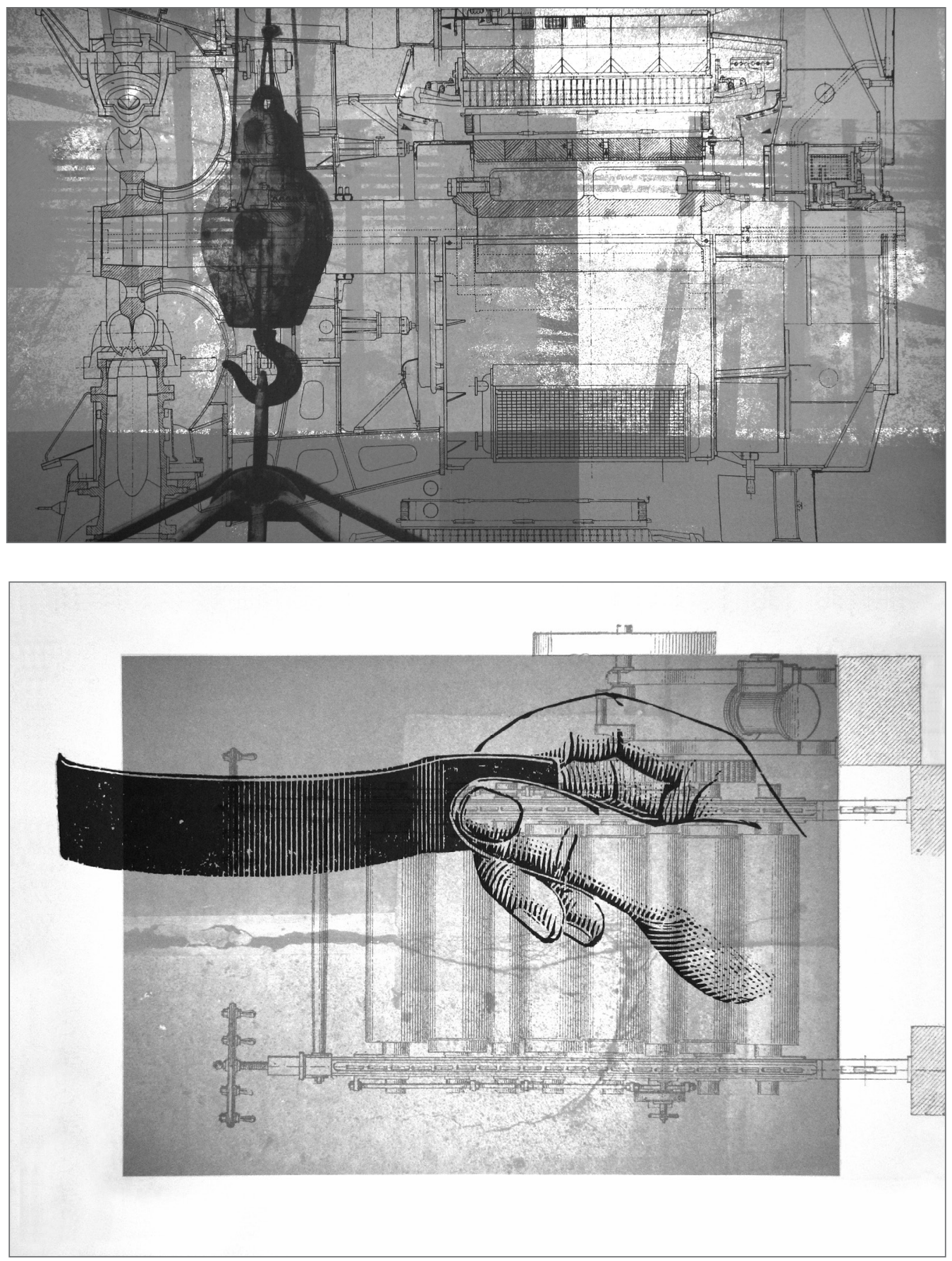

AUSART www.ehu.es/ojs/index.php/ausart

AusArt 3 (2015), 2, pp. 269-282 


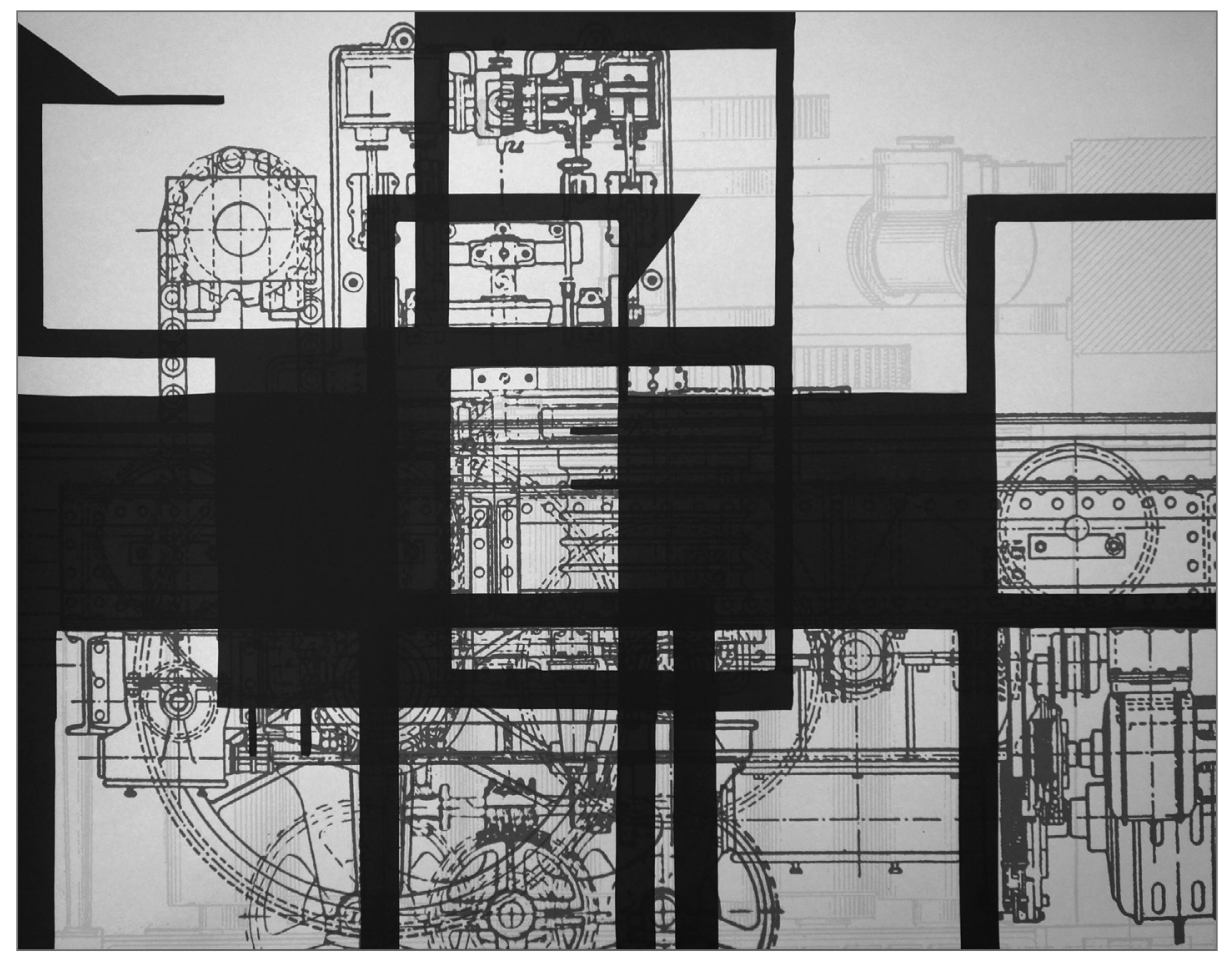

Image 10-11-12. Results

\section{PRESENTATIONS AND INSTALLATIONS}

The decision when a print is finished is rather an intuitive one. We cannot explain what criteria we have, as they can change from case to case. We try to bring form and content in a good balance and try to create constructions that evoke the most various associations. A print is only finished when we have determined its size and detail, and when we have agreed with each other. We try to find the best solution for each print and sometimes we use only a small detail of a large sheet of paper. That is why the final prints have no standard format and vary in their size an proportions. We bring the prints to a bookbinder who fixes them to an alu plate and adds a profile on the backside to give them a distance to the wall. We present the prints without glass and frame, as we arrange them in a cluster so that they build formal connections between each other. In this way the idea of modulation is continued in the form of presentation. Though it is our aim that each print can stand for itself, we perceive it to 
be a part of a subordinated installation. For each exhibition space we find a new arrangement of our works that reacts on the specific conditions of the ambience.

The Modulares Art Project is an exciting and rewarding work in progress that allows us to develop our technical interests and our concerns regarding the content continuously. In the future we plan to print on transparent materials so that we can continue the idea of modulating in spatial installations. In the Galerie Beatrice Brunner in Bern, a selection of our work that includes currently more than one hundred prints, was first shown in a single exhibition in January 2015. The jury of the Impression 2015 selected 26 of our works for the exhibition of the printmaking competition, which was shown in December 2015 and January 2016 in the Kunsthaus Grenchen. The next exhibition project will take place in April 2016 in Bilbao Bizkaia Aretoa.

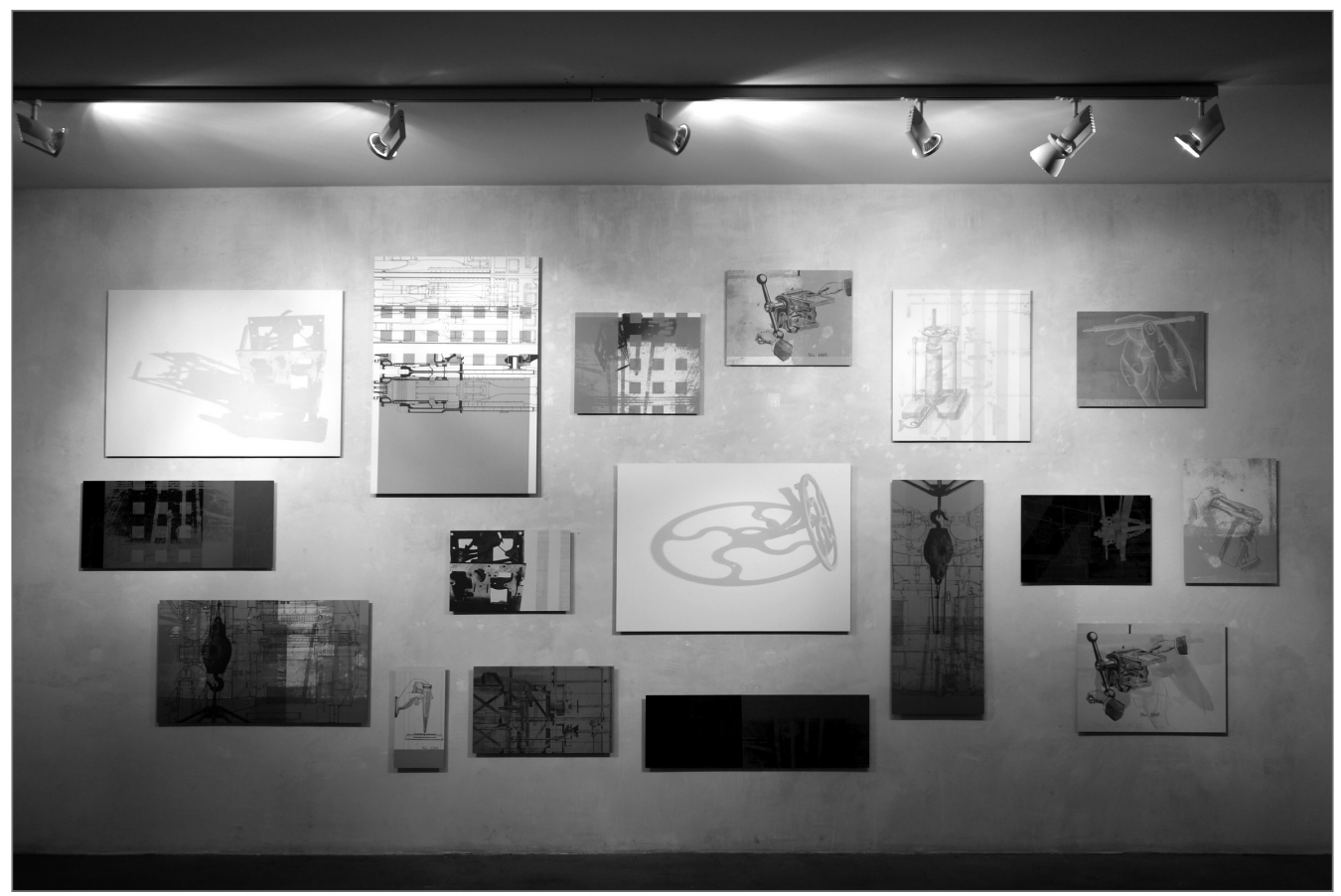

Image 13. Installation at the Gallery Beatrice Brunner Bern in 2015 


\section{References}

Becker, Jürgen \& Klaus von der Oste. 2000. Sigmar Polke: The editioned works 1963-2000. Stuttgart: Hatje Cantz

Benjamin, Walter. (1936) 1987. "La obra de arte en la época de su reproductibilidad técnica". En Discursos interrumpidos I: Filosofía del arte y de la historia, prólogo, traducción y notas de Jesús Aguirre. Madrid: Taurus

Debray, Régis. 1994. Vida y muerte de la imagen: Historia de la mirada en occidente. Traducción de Ramón Hervás. Barcelona: Paidós

Grabowsky, Beth \& Bill Fick. 2009. El grabado y la impresión: Guía completa de técnicas, materiales y procesos. Traducción Clara Melús García, Remedios Diéguez. Barcelona: Blume

Honnef, Klaus. 1991. Andy Warhol, 1928-1987: El Arte como negocio. Traducción del alemán Carmen Sánchez Rodríguez. Köln: Taschen

Hunter, Sam. 2006. Robert Rauschenberg: Obras, escritos y entrevistas. Traducción Ramón Íbero y Pérez Sánchez. Barcelona: Ed. Polígrafa

Ivins, William M. 1975. Imagen impresa y conocimiento: Análisis de la imagen prefotográfica. Versión castellana de Justo G. Beramendi. Barcelona: Gustavo Gili

Livingstone, Marco. 2000. Pop Art, a continuing history. London: Thames \& Hudson

Martínez Moro, Juan. 1998. Un ensayo sobre grabado a finales del siglo XX. Salamanca: Creativa

Pastor Bravo, Jesús. 1989. Electrografia y Grabado. Bilbao: Caja de Ahorros de Vizcaya

Simmons, Rosemary. 2005. Collecting original prints. London: A \& C

Vives Piqué, Rosa. 2003. Guía para la identificación de grabados. Madrid: Arco Libros 